\title{
Percepcija smrti i žalovanja iz dječje perspektive u pedijatrijskoj palijativnoj skrbi
}

\begin{abstract}
SAŽETAK
Neizbježna činjenica umiranja i smrti zahvaća i onaj najteži vid palijativne skrbi koja se odvija u pedijatrijskom kliničkom kontekstu. Provedba integralne pedijatrijske palijativne skrbi nužno zahtijeva sagledavanje percepcije smrti i žalovanja iz psihološko-kognitivnog i duhovno-emocionalnog kuta dječjeg iskustva „globalne boli“ koje proživljavaju u kroničnoj bolesti i/ ili njenom terminalnom stadiju. Stoga je od iznimne važnosti prilagođena komunikacija i empatijski pristup kako bi se djeca lakše nosila s neizvjesnošću i težinom svoga vlastitog stanja ili gubitka bližnjih. Palijativno ublažavanje dječjeg žalovanja može značajno biti ostvareno konstruktivnim smjernicama interdisciplinarnog pristupa razvojne psihologije, koju bi provodili svi uključeni kroz proces praćenja djece, kako bi se ostvarila holistička koncepcija palijative.
\end{abstract}

Ključne riječi: pedijatrijska palijativna skrb, smrt, žalovanje, psihologija, komunikacija.

\section{Uvod}

Unatoč činjenici da smo kao živa bića svi podložni umiranju i smrti, smrt ostaje najveća nepoznanica jer nijedna religija, kao niti ijedna znanstvena disciplina filozofije, psihologije, bioetike, medicine, ni bilo koje drugo životno područje, ne daje konačan odgovor na nelagodu i strah od smrti.

\footnotetext{
* Katolički bogoslovni fakultet u Đakovu, Sveučilište Josipa Jurja Strossmayera u Osijeku

** Studentica doktorskog studija Andrije Štampara.

**** Katolički bogoslovni fakultet u Zagrebu, Sveučilište u Zagrebu.

Adresa za korespondenciju: Suzana Vuletić, Katolički bogoslovni fakultet u Đakovu, Sveučilište Josipa Jurja

Strossmayera u Osijeku, Petra Preradovića 17, 31400 Đakovo, Hrvatska. E-pošta: suzanavuletic007@gmail.com.
} 
Iskustvo smrti proturječi čovjekovoj želji za životom, stoga je uobičajeni postupak bijeg u «zavjeri šutnje». Poseban se vid njenog potiskivanja uočava kod težih oboljenja i letalnog ishoda bolesti u djece.

Patnja i smrt nedužnog djeteta jedan je od najpotresnijih događaja životne, ali i neizbježne kliničke stvarnosti. Usprkos svim nastojanjima ostaje nužnost da se s njom suočavamo iz perspektive kliničara, roditelja, no i djeteta. Stoga nam je želja istaknuti važnost kognitivno-psiholoških i duhovno-emocionalnih konotacija pedijatrijske palijativne skrbi, ukazujući na percepciju smrti i žalovanja iz dječje perspektive ${ }^{1}$.

Palijativna skrb u pedijatriji ima svoje posebnosti u općenitom kontekstu palijativne skrbi. Ona uključuje veću mjeru znanstvene i empatijske prilagodljivosti svih osoba koje skrbe o djeci, oboljelih od kroničnih i neizlječivih bolesti.

Teškoće koje nam otežavaju takav pristup proizlaze iz nedoumica: koliko je dijete ne/svjesno svoje (kronične/terminalne) bolesti? Kakva je njegova percepcija smrti? Kako bolje razumjeti i olakšati stadije njihovog žalovanja? Kako pronaći put do ostvarenja provedbe integralne palijativne medicinske skrbi uvažavajući holistički zdravstveni pristup? Stoga ćemo se pokušati dotaknuti problematike bolesnog djeteta i odgovornosti koje za njega imaju medicinski djelatnici u suradnji s roditeljima, kako bismo mu što više nastojali olakšati stanje patnje i "globalne boli» u kojem se nalazi. Nastojat ćemo time omogućiti što primjereniju palijativnu skrb, posebno uzevši u obzir osjetljivost na uzrast i njegovo kognitivno shvaćanje te specifičnost emotivnog (ne)prihvaćanja stanja u kojem se djeca nalaze, kao i stadije žalovanja koje prolaze. To je ujedno i zahtjev Svjetske zdravstvene organizacije (SZO) koja definira pedijatrijsku palijativnu skrb kao aktivnu, potpunu brigu o tijelu, umu i duhu djeteta, uključujući i potporu obitelji ${ }^{2}$. Prema preporukama SZO-a palijativna skrb nužno zahtijeva interdisciplinarni pristup koji počinje odmah nakon postavljanja dijagnoze ${ }^{3}$ i nastavlja se neovisno o liječenju djetetove bolesti.

1 Opširniji pristup toj temi može se pronaći u: Ilija ŽIVKOVIĆ, Suzana VULETIĆ, Posljednji trenutci prije vječnosti. Teološko-bioetički naglasci shvaćanja smrti i psihološko-duhovne intervencije namijenjene umirućima $i$ ožalošćenima, HANZA media, Printera d. o. o., Sveta Nedjelja, 2016., str. 344-362.; str. 145-151.

2 Initiative for Pediatric Palliative Care (IPPC). http://www.ippcweb.org (5. svibnja 2016.)

3 Skupina djece koja će trebati palijativnu skrb jesu: djeca koja boluju od bolesti koje ugrožavaju život i neuspješno se liječe (zloćudne bolesti, ireverzibilno zatezanje bubrega, srca, jetre); djeca koja boluju od bolesti u kojima je smrt neizbježna, no kod kojih postoji period intenzivnog liječenja, koje produžuje život i kvalitetu života djeteta (cistična fibroza); djeca s progresivnim bolestima bez mogućnosti liječenja (mukopolisaharidoze, progresivne metaboličke - neurološke - kromosomske bolesti); djeca s ireverzibilnim, ali neprogresivnim stanjima s velikom oštećenjima i komplikacijama (cerebralna paraliza, trauma mozga i kralježničke moždine, malformacije...). Usp. I. PRPIĆ, J. ROGANOVIĆ, J. S. GILJEVIĆ, D. BUTKOVIĆ, M. BENKO, Pedijatrijska palijativna medicina, u: M. Brkljačić, M. Šamija, B. Belev, M. Strnad, T. Čengić (ur.), Palijativna medicina. Temeljna načela i organizacija. Klinički pristup terminalnom bolesniku. Medicinska etika, Zaklada Onkologija, Markulin d. o. o., Rijeka, 2013., str. 245 . 
Da bi se mogli zadovoljiti temeljni preduvjeti za ostvarenje učinkovite provedbe pedijatrijske palijativne skrbi svi bi uključeni sudionici interdisciplinarnog palijativnog tima (ali i sami roditelji) trebali biti svjesni (i)realnosti dječje percepcije boli i umiranja.

\section{Dječje iskustvo „globalne“ boli i hospitalizam}

Djeca teškoću bolesti i smrti proživljavaju na svojstven način, sukladno njihovoj mogućnosti shvaćanja i prihvaćanja.

Odnos prema bolesti ${ }^{4}$ ovisi o mnogim faktorima koji su međusobno isprepleteni, kao što su: starost djeteta, njegova osobnost, tip bolesti, stadij bolesti, jačina bolova, medicinska prognoza, uvjeti rehabilitacije, kronična ili terminalna faza, potpora obitelji, iskrenost bližnjih, emotivna ili duhovna zahvaćenost žalovanja, adekvatna liječnička i palijativna skrb...

Za razliku od odraslih, djeca se ne mogu usredotočiti na nešto drugo, osim na bol koju osjećaju, a koju dodatno potiče izolacija iz poznate sredine, prijateljskog okružja i domaće kućne atmosfere. U hospitalizirane djece uočava se tzv. «globalna bol». Ta bolna patnja nije uzrokovana samo fizičkim bolovima, već i psihološkim strahom od bolnosti, osjećajem napuštenosti, tjeskobe i drugih životnih isključenosti, kao i izbivanjem iz poznate sredine. Stoga se u djece učestalije javlja hospitalizam kao odraz psiholoških i tjelesnih poremećaja uzrokovanih dugotrajnim boravkom u bolnici, hospiciju, dječjem domu ili drugoj ustanovi.

Kriva je pretpostavka smatrati da djeca koja boluju od malignih bolesti nisu svjesna ozbiljnosti svoga stanja te da nisu sposobna razumjeti ozbiljnost takve dijagnoze, pa ih je stoga bolje zaštititi od tereta koji to saznanje nosi sa sobom. $S$ pouzdanošću se može reći kako čak i mlađa djeca vrlo realno shvaćaju svoju bolest ${ }^{5}$, a osobito se to odnosi na stariju djecu i adolescente.

4 Djeca mogu imati jedan od stotine definiranih metaboličkih ili enzimskih nedostataka (npr. mišićna distrofija, cistična fibroza, Pearsonov sindrom); kromosomske i genetske anomalije (npr. trisomija 5, 13, 18, Rettov sindrom); razvojnih defekata (problemi s migracijom stanica i sazrijevanja tijekom fetalnog razvoja, uključujući anencefalije i hipoplastični sindrom lijeve klijetke srca); komplikacije nezrelosti i drugih oblika majčine/fetalne nekompatibilnosti; perinatalne infekcije; teške ozljede mozga, cerebrovaskularne bolesti (moždani udar), hipoksija, metaboličke bolesti (npr. sepsa), traumatske ili druge životno ugrožavajuće bolesti. Usp. M. LEVETOWN, S. ORLOFF, Ethical Issues in the Care of Infants, Children, and Adolescents, u: T. W. Kirk, B. Jennings, Hospice Ethics. Policy and Practice in Palliative Care, Oxford University Press, New York, 2014., str. 82.; P. W. NEWACHECK, N. HALFON, Prevalence and impact of disabling conditions of childhood, u: American Journal of Public Health 88 (1998.) 4., 610-617.

5 Usp. M. RUKAVINA, Komunikacija s teško bolesnom djecom i mladima, u: D. Lučanin, J. Despot Lučanin (ur.), Komunikacijske vještine u zdravstvu, Zdravstveno Veleučilište, Naklada Slap, Jastrebarsko, 2010., str. 195. 
Već od prvih mjeseci svog razvoja djeca mogu izražavati svoje osjećaje: straha, ljutnje, ugode, ne/zadovoljstva, tuge i radosti. Znanstveno su dokumentirani već novorođenčetovi bolovi, a provedene su i studije koje pokazuju da se već i dijete (ispod navršene godine dana starosti) može prisjetiti bolne situacije. Iako malo dijete nije sposobno objektivno komunicirati svoju bol, niti je verbalizirati, ono ima svoj način priopćavanja (želja za neprestanom blizinom roditelja/njegovatelja, strah, plač, povlačenje...).

Potkraj prve godine dijete već jasnije očituje svoje emocije s većom učestalošću, jasnoćom i spremnošću. U drugoj godini, zahvaljujući kognitivnim pomacima, djeca postaju svjesnija kompleksnijih osjećaja.

U trećoj godini pa nadalje, dijete često misli da je njegova bolest rezultat nekog neposluha ili kazna za neke prekršaje. Stoga smatra da se i zdravlje može ponovno vratiti ako popravi svoje ponašanje.

U predškolskoj i školskoj dobi sposobnost verbaliziranja djetetova stanja u kojem se nalazi znatno se usavršava, no unatoč tome teško mu je definirati bol u nekim kvalitativnim i kvantitativnim terminima ${ }^{6}$.

Pojedini stručnjaci iz područja dječje psihologije i pedijatrije smatraju da stadiji razumijevanja teške ili kronične bolesti slijede kronološki napredovanje same bolesti te govore o pet stadija: ${ }^{7}$

1) Bez obzira na dob, djeca tijekom prve faze shvate da su ozbiljno bolesna i da boluju od neke teže bolesti (kao što je, primjerice, rak), iako postoji određeni period neizvjesnosti, prije nego što se postavi točna dijagnoza.

2) U drugom stadiju pojavljuje se shvaćanje da imaju bolest od koje neki ljudi umiru. Neka djeca mogla su na odjelu čuti riječ kao što je leukemija i tako shvatiti da je ona nekako povezana sa smrću.

3) U trećem stadiju dolaze do saznanja da imaju bolest od koje umiru i djeca. Kako njihovo stanje deteriorira, djeca postaju svjesna ciklusa relapsa i remisija bolesti. U ovoj fazi još uvijek ne znaju da se neće oporaviti.

4) Četvrti stadij odnosi se na vrijeme potrebno da se dijete nauči nositi sa spoznajom kako nikad neće ozdraviti. Ovaj stadij vrlo je često povezan s depresijom i rezignacijom te je potrebno reagirati ako se takvi simptomi zamijete kod djece. Moguće je da djeca

6 Usp. P. H. MUSSEN, J. J. CONGER, J. KAGAN, A. C. HUSTON, Lo sviluppo del bambino e la personalità, Zanichelli, Bologna, 1994.

7 Usp. R. LANSDOWN, Children ih hospital. A guide for family and carers, Oxford University Press, Oxford, 1996. 
dožive i vide različite stvari poput, primjerice, smrti drugog djeteta na odjelu, što može potaknuti spomenute procese.

5) U petom, posljednjem stadiju, dijete razumije da će umrijeti. Psiholozi razvojne psihologije smatraju da sva djeca starija od 3 godine dođu u taj stadij, iako je teško procijeniti koliko dijete zaista razumije.

Ovih pet stadija mogu zdravstvenim djelatnicima pružiti određene smjernice o tome kako postupati, ovisno o stadiju bolesti i razumijevanju koje dijete iskazuje. Ključ svim stadijima je iskrenost, empatija, prilagođenost i stalna pratnja.

Vrlo je važno imati na umu da oboljela djeca trebaju imati odgovarajuću razinu znanja o stanju u kojem se nalaze, te im treba dati primjerenu dozu razumijevanja, bilo u obitelji, bilo na bolničkom odjelu. Zato bolesna djeca trebaju imati poseban vid zaštite i prikladne informacije ${ }^{8}$, prilagođene njihovoj mogućnosti shvaćanja, što je posebice važno ako prognoza bolesti nije dugoročnog predviđanja.

Osim percepcije boli, nužno se moramo suočiti i s temom kognitivne percepcije smrti kod djece, bilo da im ona predstoji osobno ili je doživljaju gubitkom bližnjih.

\section{Kognitivna percepcija smrti iz dječje perspektive}

Psihologija ljudskog razvoja detaljnije proučava načine kako djeca razvijaju svoju percepciju, misaone procese, emotivne reakcije, duhovni pristup i ostale načine nošenja i suočavanja s pojedinim fenomenima kojima se susreću u bolesti.

Boravkom u bolnici djeca stječu sve više informacija o svojoj bolesti kroz osobno iskustvo i iskustvo drugih te postupno postaju svjesni svoje prognoze.

Istraživanja potvrđuju da već djeca u dobi od 3. do 6. godine imaju poprilično jasne predodžbe o smrti, neovisno o tome što mi mislimo da ih nemaju. Čak i ako roditelji ili zdravstveni stručnjaci nisu s njima otvoreni, djeca spoznaju da su smrtno bolesna na druge načine (neverbalnom komunikacijom, prisluškivanjem ili u razgovoru s drugim pacijentima). Djeca shvaćaju da boluju od nečeg jako lošeg i neizlječivog, neovisno o tome jesmo li im to dali do znanja ili nismo. Oni to potvrđuju izjavama: Znam da sam jako bolestan; Imam bolest od koje se umire; Znam da mi ne može biti bolje; Osjećam da umirem...

8 Usp. A. GOLDMAN, R. HAIN, S. LIBEN (ur.), The Oxford Textbook of Palliative Care for Children, Oxford University Press, New York, 2006. 
Da bismo shvatili psihološko poimanje smrti, smatramo bitnim objasniti kako se ona percipira u pojedinim uzrastima9.

Tablica 1. Poimanje smrti u pojedinim razdobljima dječjeg uzrasta ${ }^{10}$

\begin{tabular}{|c|c|}
\hline Djeca do 3 godine & Djeca od 3 do 7 godina \\
\hline $\begin{array}{ll}\checkmark & \text { nemaju rječnik za imenovanje osjećaja } \\
\checkmark & \text { nemaju sposobnosti da shvate gubitak } \\
\checkmark & \text { nemaju pojam vremena ni budućnosti } \\
\checkmark & \text { smrt i odsutnost imaju isti učinak }\end{array}$ & $\begin{array}{ll}\checkmark & \begin{array}{l}\text { personificiraju i mistificiraju smrt } \\
\text { (kostur, anđeo) }\end{array} \\
\checkmark & \text { ne razumiju gubitak, ali su ga } \\
& \text { intuitivno svjesna } \\
\checkmark & \text { tjelesni simptomi } \\
\checkmark & \text { poremećaji spavanja } \\
\checkmark & \text { nemaju rječnik kojim bi izrazili što } \\
& \text { osjećaju } \\
\checkmark & \text { teškoće u koncentraciji i dosjećanju } \\
\checkmark & \text { doživljavaju smrt kao kaznu } \\
\checkmark & \text { postavljaju pitanja }\end{array}$ \\
\hline
\end{tabular}

\begin{tabular}{|ll|ll|}
\hline \multicolumn{2}{|c|}{ Djeca od 7 godina do adolescencije } & \multicolumn{1}{|c|}{ Adolescenti } \\
\hline$\checkmark$ & razumiju neizbježnost i nepovratnost & $\checkmark$ & potpuno razumiju konačnost i prirodu \\
smrti & smrti \\
$\checkmark$ & zabrinutost za sigurnost bližnjih i sebe & $\checkmark$ & osjećaj besmisli ili želja za osvetom \\
$\checkmark$ & teškoće u koncentraciji i dosjećanju & $\checkmark$ & osjećaj gubitka kontrole u životu \\
$\checkmark$ & osjećaj gubitka kontrole & $\checkmark$ & nemogućnost odlučivanja \\
$\checkmark$ & poremećaj spavanja & $\checkmark$ & teškoće u koncentraciji \\
$\checkmark$ & tjelesni simptomi & $\checkmark$ & gubitak samopoštovanja \\
$\checkmark$ & pokazuju emocije & $\checkmark$ & izražavaju emocije \\
$\checkmark$ & povlače se & $\checkmark$ & osjećaj krivnje \\
\hline
\end{tabular}

9 Za iscrpan prikaz pojedinih faza: P. R. SILVERMANN, Never too young to know, Oxford University Press, Oxford, 2000.; J. H. HENDRIKS, D. BLACK, T. KAPLAN, Guiding Children through Trauma and Grief, Routledge, London, 2000.; C. A. CORR, D. E. BALK (ur.), Handbook of Adolescent Death and Bereavement, Springer Publishing Company, 1996.

10 Usp. L. ARAMBAŠIĆ, Gubitak, Tugovanje, Podrška, Naklada Slap, Jastrebarsko, 2008. ${ }^{2}$, str. 164-180. Za opširniji pristup doživljaju smrti, umiranja i tugovanja: A. DYREGROV, Tugovanje u djece, EDUCA, Zagreb, 2001. 
Predškolska djeca često na smrt reagiraju ponašanjem koje ukazuje na anksioznu privrženost, plačem, željom da ih se nosi, potrebom za neprekidnim umirivanjem... U toj dobi djeca često imaju povećan strah od odvajanja i odbijanja te su osjetljivija na najavu predstojeće im smrti zbog neizlječive bolesti koja ih pogađa ili je proživljavaju smrću bližnjega. Bolesno dijete može se udaljavati od druge, zdrave djece ili pak izbjegavati prisutnost onih koji ga previše podsjećaju na voljenu osobu, ako su doživjeli gubitak bliskog obiteljskog člana.

Djeca do 3. godine ne znaju još ništa o značenju smrti, nemoguće im je objasniti njenu konačnost, iako dijete itekako može svjesno pokazivati gubitak privrženosti nekih osoba (npr. gubitak majke već novorođenče može izraziti neprestanim histeričnim plakanjem).

Između 3. i 5. godine smrt se ne shvaća kao univerzalna i konačna pojava, nego se interpretira kao odlazak na put ili spavanje ili samo kao privremena $\mathrm{smrt}^{11}$.

Oko 5. godine dijete već može percipirati smrt kao separaciju ili napuštanje. Zbog poremećaja u skrbi može se javiti protestiranje i očaj.

Predškolci se oslanjaju na egocentrično i magično mišljenje. Iako mlađa djeca mogu početi osjećati da drugi ljudi umiru, ona ignoriraju značenje smrti. Predškolci mogu povjerovati da su odgovorni za nečiju smrt. Nedostatak razumijevanja onoga što se dogodilo može dovesti do iskrivljavanja stvarnosti. Mogu se ljutiti na svoje roditelje jer smatraju da roditelji trebaju popraviti nečiju smrt kao što mogu popraviti potrganu igračku. Dijete povremeno osjeća da je smrt povratan proces, ako je netko dobar. Tako se uočava personifikacija smrti.

Za mlađu je djecu smrt neka drugačija faza života, a ne stanje odvojenosti. Smrt za neke znači biti manje živ ${ }^{12}$. Pojedina djeca misle ${ }^{13}$. ... da su poslije smrti opet budni. Samo se zločesti ljudi ne bude... (dijete, 3 godine); Smrt je kada skinete svoje tjelesno odijelo od mesa (dijete, 5 godina); Kada dodete $k$ Bogu, on vas onda ucini cijelima. (dijete, 5 godina). Smrt znači jako čvrsto spavanje. Ako ste u životu bili važni i dobri drugima, tada vas "Bogo" probudi. Ako niste bili dobri, tada vas pusti da dugo spavate $i$ nitko vas ne budi. A dok spavate, vama se ništa ne dešava i nemate se priliku igrati i nije vam zanimljivo. Mala su djeca ovakvim predodžbama zaštićena time što nisu razvila sposobnost razumijevanja dugoročnoga značenja događaja.

11 Kada odrasli koriste klišeje ili daju pogrešne izjave, djeca ih mogu shvatiti doslovno i biti zbunjena. Na primjer, nakon što je majka rekla svojoj petogodišnjoj kćeri da je djed otišao na dug put, dijete je pitalo: „A zašto mene nije poveo?"“ Otac čija je supruga umrla od raka rekao je svome sinu samo da je majka bila bolesna. Bio je iznenađen kad je nakon nekoliko mjeseci sin dobio gripu i počeo se strašno bojati da će i on umrijeti.

12 Usp. M. ŠTIFANIĆ, Kultura umiranja, smrti i žalovanja, Adamić, Rijeka, 2009., str. 127-133.

13 Usp. P. NEYSTERS, K. H. SCHMITT, Denn sie werden getröstet werden. Das Hausbuch zu Leid und Trauer, Sterben und Tod, Kösel-Verlag GmbH \& Co, München, 2004., str. 185. 
Djeca od 5. do 8. godine postupno razvijaju razumijevanje ireverzibilnosti i konačnosti smrti.

Dijete školske dobi povećava napore da shvati biološku smrt u nadi da će naučiti kako kontrolirati i izbjeći neizbježno. Djeca se oko 8. godine identificiraju s umrlom osobom i postaju svjesna mogućnosti vlastite smrti. Smrt se prepoznaje kao neizbježan kraj života i govorimo već o realističnoj fazi. Da bi naučila određene načine kontrole toga događaja, djeca postavljaju brojna pitanja, prihvaćaju iskustva drugih osoba i slobodno raspravljaju o tom problemu. Školska djeca raspolažu većim brojem strategija za suočavanje sa smrću i kriznim situacijama. No djeca u toj dobi mogu patiti zbog dodatnih poteškoća, jer se pred njih postavljaju veći zahtjevi (da budu jaki, da ne plaču...). Za tu je dob tjeskoba uobičajena reakcija. Može se pojaviti i tendencija $\mathrm{k}$ izoliranju od vršnjaka i nesposobnost dijeljenja osjećaja s odraslima i vršnjacima ${ }^{14}$.

$\mathrm{U}$ adolescenciji se javlja velika doza tjeskobe pred smrću. Adolescenti teško prihvaćaju smrt zbog vlastitih nesigurnosti i potrebe za osloncem koji su mislili imati u izgubljenoj osobi. U adolescenciji se smrt člana najuže obitelji doživljava katkada kao stigma, tj. kao nešto što treba skrivati i čega se treba stidjeti. To stanje psiholozi nazivaju "praznim prostorom adolescencije» ${ }^{15}$. Njihova psihološka oznaka snažnoga egocentrizma ostavlja im dojam kako nitko ne može razumjeti što prolaze. Intenzitet osjećaja u adolescenciji može dovesti do potiskivanja osjećaja ili izbjegavanja suočavanja s njima zbog straha od gubitka kontrole nad silnim emocijama. To se događa posebice dječacima koji su, djelovanjem različitih utjecaja, naučili da se osjećaji ne smiju izravno pokazati. Zato se te reakcije više izražavaju u ponašanju i sukobima s okolinom. Adolescenti mogu postati kritičniji prema sebi, osobito ako vjeruju da su mogli nešto učiniti da spriječe nesretan događaj. Oni često reagiraju na smrt protestom i neprilagođenim ponašanjem. Neki će, pak, tražiti opasna iskustva u kojima će pokušavati steći osjećaj kontrole nad smrću.

Ako je riječ o predstojećoj smrti nekoga adolescenta, terminalni adolescenti više su zabrinuti za svoje obitelji nego za sebe. Vlastita smrtnost ili smrt njihovih bližnjih ostavlja ih u stanju potpune bespomoćnosti i ranjivosti, preplašene i depresivne, izolirane $\mathrm{i}$ indiferentne.

Neki pak smatraju kako tragedija u mladosti potiče bolje i brže sazrijevanje, veće cijenjenje života, jaču emocionalnu snagu, razvijanje sposobnosti boljeg rješavanja problema, jačanje društvenih veza i veću otvorenost. No za tu se ostvarenost zahtijeva prilagođena komunikacija. Otvorena i iskrena rasprava s djecom pridonosi

14 Za opšiniji pristup: A. DYREGROV, Tugovanje u djece, EDUCA, Zagreb, 2001.

15 Usp. S. FLEMING, L. BALMER, Bereavement in Adolescence, u: C. A. Corr, D. E. Balk (ur.), Handbook of Adolescent Death and Bereavement, Springer Publishing Company, 1996., str. 187. 
realističnom razumijevanju smrti i olakšava anticipirano žalovanje, nakon što djetetu predstoji neposredan gubitak vlastitog zdravlja i života, ili mu se pokušava potaknuti lakše prolaženje kroz stadije žalovanja, ako je dijete doživjelo gubitak bliske osobe.

\section{Važnost prilagođene komunikacije za lakše shvaćanje i prihvaćanje smrti u pedijatrijskom kontekstu}

Djeca bi trebala biti upućena u teške teme, poput neizlječive prognoze, težine bolesti, predstojeće smrti, tugovanja i žalovanja. No, kao posljedica želje da ih se zaštiti, često ostaju prikraćena, bez adekvatne informacije i prilagođene komunikacije.

Zahtjevom roditelja, kao zakonskih zastupnika i skrbnika, djeci se najčešće nastoje prešutjeti određene informacije koje se tiču njihovog teškog zdravstvenog stanja. Roditelji mogu zastupati to mišljenje iz uvjerenja kako su djeca premala da bi ih se opterećivalo zastrašujućim činjenicama ili da bi razumjela što im se događa. Isto tako, roditelji mogu na taj način izbjegavati pitanja o umiranju i smrti ili pokušati sprječavati uznemirenost djeteta. Ponekad to mogu činiti iz pobuda i težine vlastite nemogućnosti prihvaćanja i nošenja sa spoznajom da za svoje dijete ne mogu učiniti ništa više.

Važno je znati da izbjegavanje razgovora s djecom može kod njih izazvati osjećaje izoliranosti i daljnjeg nepovjerenja u odrasle osobe, posebice ako nemaju s kim podijeliti svoje strahove, brige i sumnje koje vjerojatno osjećaju. U situacijama kada roditelji i dalje odbijaju dati dopuštenje da se djetetu i adolescentu daju bilo kakve informacije, potrebno je naći ravnotežu između prava djeteta na informaciju i prava obitelji da odaberu koji je najbolji način za nošenje s djetetovom bolešću.

Zdravstveni djelatnici trebali bi se zalagati za iskren pristup u radu s djecom i mladima, s naglaskom na adekvatnom informiranju djece o njihovoj bolesti.

Psihološka i duhovna istraživanja utvrdila su kako su djeca koja dobivaju otvorene i iskrene informacije o dijagnozi i prognozi rano tijekom svoje bolesti značajno manje tjeskobna i depresivna i navode više izvora pomoći i socijalne podrške od djece koja ne dobivaju primjerene informacije od roditelja.

Razumijevanje pojma smrti ovisi o dobi i sposobnostima te o obilježjima kulture u kojoj se odrasta. „Način na koji će djeca početi stvarno razmišljati o smrti ovisi o načinu na koji im roditelji objašnjavaju pitanja o tome i o njihovom osobnom shvaćanju života i smrti“"16.

16 R. FULGHUM, Od rođenja do smrti. Obredi u našem životu, Mozaik knjiga, Zagreb, 1997., str. 195. 
Djeca vrlo često predosjećaju ili znaju da će umrijeti, što vodi do osjećaja goleme izolacije ako im roditelji ne daju dozvolu da govore o svojoj bolesti, smrti i strahovima.

Kada dijete inicira razgovor, važno je biti otvoren i iskren te prilagođen mogućnostima shvaćanja djeteta. Slijede neki korisni savjeti za uspješna ostvarenja: ${ }^{17}$

Ako nas dijete pita: Mogu li umrijeti od te bolesti, odgovor može biti: To je vrlo ozbiljna bolest i neka djeca umru. No, doktori koriste najbolje lijekove koje imaju kako bi te izliječili i nadaju se da će ti lijekovi pomoći.

Ako je dijete svjesno mogućnosti da će umrijeti, važno je naglasiti kako su roditelji i zdravstveni djelatnici učinili sve kako bi mu pomogli da ozdravi. Potrebno je objasniti kako se bolest nije povukla i da lijekovi više ne pomažu.

Djeci i mladima potrebno je dati do znanja da će imati potporu bez obzira koliko je to razdoblje teško za sve koji su se kroz mjesece, a ponekad i godine liječenja, brinuli o djetetu.

Uvijek treba ostaviti nadu u drugačiji ishod, ako je to važno djetetu i obitelji.

Poznavanje istine povećava osjećaj kontrole nad bolešću i suradnju djeteta u liječenju. Ako se dijete izbjegava informirati i poučiti; ako njegova pitanja ostanu bez ikakvih odgovora, njegova će se tjeskoba i strah samo dalje uvećavati. Zato pedijatrijska palijativna skrb zahtijeva posebne komunikacijske vještine is djecom i roditeljima.

U svrhu što lakše komunikacije navodimo nekoliko savjeta za liječnike i roditelje o tome kako razgovarati: ${ }^{18}$

- Preuzmite inicijativu. - Obratite pozornost na neverbalna ponašanja djece i adolescenata te otvorite temu na sućutan način!

- Pažljivo slušajte. - Posvetite djetetu punu pozornost, kao i osjećajima koji se nalaze u pozadini izgovorenih riječi!

- Pokažite da prepoznajete osjećaje. - Prihvatite djetetove emocije kao stvarne i važne!

- Dajte točne informacije na osjetljiv način. - Djeci koja još ne razumiju na realističan način trajnost, univerzalnost i nefunkcionalnost smrti ponudite jednostavna, izravna i točna objašnjenja, izbjegavajući izjave koje vode u zabludu!

- Zajednički rješavajte probleme. - Kada pitanja nemaju lagan odgovor, potvrdite da je mlada osoba vrijedna tako što ćete reći da ne želite nametnuti svoje stajalište, nego joj želite pomoći da dođe do zaključka koji će je osobno zadovoljiti!

17 Usp. M. RUKAVINA, Komunikacija s teško bolesnom djecom i mladima, u: D. Lučanin, J. Despot Lučanin (ur.), Komunikacijske vještine u zdravstvu, Zdravstveno Veleučilište, Naklada Slap, Jastrebarsko, 2010., str. 200.

18 Usp. E. L. BERK, Psihologija cjeloživotnog razvoja, Naklada Slap, Jastrebarsko, 2008. 
- Iskrenost - Na pitanja na koja ne možete odgovoriti recite da ne znate! Iskrenost pokazuje spremnost da zajednički nađete moguća rješenja.

Podcjenjivanje dječje sposobnosti i nepriznavanje njihove prave vrijednosti u djece mogu probuditi ljutnju i ogorčenje. Jačina straha i zbunjenosti koju izazivaju u njima brojna neodgovorena pitanja ovise o djetetovoj dobi i o tome na kojem je dijete razvojnom stupnju. Zbog toga je još dodatno iznimno važno da dijete i u tom okružju pronađe nekoga u kome će moći imati siguran oslonac i za koga će biti uvjereno da mu neće tajiti informacije vezane uz njegovo stanje, te da će, postupajući uz puno poštovanje svoje profesionalnosti, uvažavati sve potrebne stavke.

Da bismo pomogli djeci da što manje traumatično prođu ovo razdoblje potrebno je da djetetu osvijestimo stanje u kojem se nalazi, kao i ona s kojima će se još trebati suočavati, i to bez dihotomije onoga što mu priopćavaju roditelji, a što liječnici i medicinske sestre.

Odrasli se, napose roditelji, boje razgovarati o smrti pred djecom, a pogotovo ako je indikativno da mogu iščekivati skoro nadolazeću smrt vlastitog djeteta. Razlozi njihova opravdanja i više su nego tragični jer roditeljima nameću dodatnu bol u nemoći da se išta više učini. No, djeca se isto tako trebaju pripremiti za ono što neminovno slijedi. Treba s prirodnošću i ležernošću govoriti pred djetetom o bolesti i njenom izvoru, točno i ispravno, bez pretjeranog dramatiziranja. Premda dijete i ne razumije u potpunosti mistificirani jezik kojim komuniciraju liječnik i njegovi roditelji, dijete ima pravo znati svoje stanje. Iako se pred njim nastoje zatajiti nepredvidljivosti uzurpirajuće bolesti, dijete uviđa da su roditelji uznemireni liječnikovim pristupom.

Pri komunikaciji s djecom koja primaju palijativnu skrb liječnik mora uzeti u obzir specifične čimbenike kao što su: razvojne faze djeteta, razina djetetova razumijevanja i tumačenje bolesti ili liječenja. Informacije koje se daju djetetu trebaju biti prilagođene njegovu razvojnom i kognitivnom nivou, uzimajući u obzir individualne razlike, odnosno, potrebno je prvo provjeriti koliko dijete zna o specifičnoj situaciji ${ }^{19}$. Stoga je potrebno: ${ }^{20}$

- Razgovarati s djecom i slušati ih kako biste uočili imaju li pogrešne zamisli o smrti!

- Potaknuti dijete da lutkama predstavi događaj kako biste bolje uvidjeli na koji način razmišlja o smrti!

19 Usp. S. KREITLER, M. WEYL BEN ARUSH, Psychosocial aspects of pediatric oncology, Wiley, Chichester, 2004.; K. LACKOVIĆ-GRGIN, Stres u djece i adolescenata, Naklada Slap, Jastrebarsko, 2000.

20 Usp. F. P. GLASCOE, Suradnja s roditeljima. Upotreba roditeljske procjene dječjeg razvojnog statusa - PEDS u otkrivanju razvojni h problema i problema ponašanja te bavljenju tim problemima, Naklada Slap, Jastrebarsko, 2002., str. 64 . 
- Obratiti pozornost na neverbalno ponašanje djece te otvoriti temu na sućutan način!

- Prihvatiti djetetove emocije kao stvarne i važne, a izbjegavati osuđivanje i/li omalovažavanje!

Djeci s kroničnom bolešću trebalo bi pristupati sa senzibilnošću, isto kao i onoj djeci u terminalnoj fazi kojoj je s posebnom pažnjom potrebno dati naslutiti skoro nadolazeću smrt. O njoj djeca imaju, sukladno određenoj dobi, svoju vlastitu viziju, popraćenu strahom od odvajanja, razdvajanja ili gubitka...

Zahvaljujući studijama razvojne psihologije i ostalih relevantnih znanstvenih grana potvrđena je sposobnost djece da svjesno utječu na svoje izbore i zahtjevne odluke u svoje ime ${ }^{21}$, što u određenoj mjeri može biti ključno u ispravnoj provedbi pedijatrijske palijative.

„Individualni pristup djetetu ovisi o njegovoj dobi, kognitivnoj i emotivnoj zrelosti te strukturi i funkcioniranju obitelji. U komunikaciji s djetetom u poodmaklom stadiju bolesti u bilo kojem trenutku istina nije ni princip, ni obveza, ni pravilo. Istina je atmosfera razmjene, slušanja, uvažavanja djeteta i njegovih potreba"22. Ako je dijete istinsko svjesno svog stanja, omogućit ćemo mu da njegovo žalovanje bude što manje tragično i morbidno.

\section{Percepcija žalovanja kod djece kojoj prijeti neposredna vlastita smrt ili tugovanje za bližnjima}

U pedijatrijskoj palijativnoj skrbi trebali bismo biti svjesni načina dječjeg nošenja s gubitcima i posljedičnog žaljenja.

I djeca žaluju na sebi svojstven način koji se često podcjenjuje mišlju da ona ne shvaćaju konačnost smrti (bilo da im ona prijeti osobno ili su je doživjeli iz perspektive promatrača, gubitkom njima bliske osobe).

Iako je opći kognitivni razvoj djeteta povezan i s razumijevanjem smrti, rezultati pokazuju da dijete kojem predstoji neposredna vlastita smrt ili je smrt doživjelo smrću bliske osobe ili nekoga poznanika, kojemu je pružena kvalitetna potpora u procesu tugovanja, bolje prihvaća tu životnu činjenicu od druge djece.

21 Usp. O. SAHLER, G. FRAGER, M. LEVETOWN, F. COHN, M. LIPSON, Medical education about end-of-life care in the pediatric setting: Principles, challenges, and opportunities, u: Pediatrics 105 (2000.) 3., str. $575-584$

22 I. PRPIĆ, J. ROGANOVIĆ, J. S. GILJEVIĆ, D. BUTKOVIĆ, M. BENKO, Pedijatrijska palijativna medicina, u: M. Brkljačić, M. Šamija, B. Belev, M. Strnad, T. Čengić (ur.), Palijativna medicina. Temeljna načela i organizacija..., str. 237. 
Bilo bi dobro da to priopćavanje učini i pruži potporu osoba vrlo bliska djetetu, da ga mentalno i emocionalno pripravi na ono što slijedi ili se već dogodilo.

Djetetu treba objasniti događaj pojmovima koji su prihvatljivi za njegovu dob. Obavijest o neminovno nadolazećoj ili ostvarenoj smrti treba biti konkretna i izravna kako ne bismo u djetetu izazvali još veću pomutnju.

Neposredne reakcije na takvu vijest mogu biti vrlo različite, pa je potrebno osigurati primjeren prostor da ih dijete može slobodno izraziti. Na pitanja koja tada mogu postavljati treba im dati konkretne odgovore, bez umanjivanja ili iskrivljivanja stvarnosti ${ }^{23}$.

Reakcije koje se tada javljaju u djece mogu biti sljedeće: ${ }^{24}$

- Šok i nevjerica - Poneka djeca ne žele vjerovati u tešku vijest koja im je saopćena. Mogu smatrati da se to nije moglo, niti smjelo dogoditi, niti takvo što može uslijediti. Mogu sumnjati u istinitost saopćenog.

- Očaj i protest - Neka djeca mogu biti posve neutješna i reagirati protestnim ponašanjem. Ispadi gnjeva mogu se očitovati u obliku prosvjeda, neposluha i traženja više pažnje.

- Apatija - Pojedinci se mogu činiti kao okamenjeni te neposredno na vijest o gubitku mogu pitati: Mogu li se ići van igrati? ili se ponašati kao da se ništa loše nije dogodilo.

- Tjeskoba - Kod neke se djece uviđa strah od gubitka pa postaju tjeskobna, povučena, izolirana, usamljena.

- Strah - Najčešća dječja reakcija kod priopćenja loše vijesti/dijagnoze/ gubitka voljene osobe.

- Smetnje spavanja uobičajene su u djece koja tuguju; vezane su uz pojačanu tjeskobu; mogu se javljati učestale noćne more, te se dijete boji snova, ili se mogu pojaviti mokrenja u krevet.

- Tuga i čežnja - česte pojave uočljive kod djece koja se osamljuju, izoliraju, povlače ili pak češće traže blizinu odraslih.

- Preokupacija uspomenama - nekima se čini olakšavanje gubitka gledanjem slika u fotoalbumu. Neka djeca koja su izgubila njima privrženu osobu mogu nesvjesno oponašati pokojnika, nositi njegove predmete ili ga oponašati te se tako osjećaju bliže dragoj osobi koje više nema.

23 Prilagođene primjere koji pokazuju kako razgovarati s djetetom koje je doživjelo gubitak, što mu reći, a što ne govoriti, nalaze se na stranicama Poliklinike za zaštitu djece grada Zagreba, www.poliklinika-djeca.hr.

24 Usp. A. DYREGROV, Tugovanje u djece..., str. 14-31. 
- Ljutnja i ispadi gnjeva očituju se kao ljutnja na smrt, na odrasle, na Boga, na sebe same ili na voljenu osobu koja ih je napustila.

- Krivnja i samooptuživanje javlja se kao jedan od mehanizama nošenja s osjećajem bespomoćnosti.

- Teškoće u učenju - uobičajene su nuspojave manjka koncentracije i pozornosti, smanjenog uspjeha u školi, a ponekad i odbijanje odlaska u školu.

- Psihosomatske tegobe javljaju se u obliku glavobolja, bolova u želudcu, tahikardije, mišićne napetosti i sl.

- Reakcije u obliku regresivnoga ponašanja, socijalne izolacije, fantazija, promjena u ličnosti, pesimizmu glede budućnosti, zaokupljenosti uzrokom i značenjem te sazrijevanje i odrastanje.

Osjećaj bespomoćnosti koji odrasli imaju kad ne mogu ukloniti djetetovu bol i patnju, kad im je teško gledati dijete koje neutješno plače zbog gubitka koje je doživjelo, makar se njima samima činio besmislen i nevažan, trebaju prihvatiti i dopustiti djetetu da izrazi svoju tugu. Potrebno je otvoreno razgovarati s djetetom o tome što osjeća; dopustiti mu da se isplače; omogućiti mu, ako je moguće, da se s pomoću određenoga rituala oprosti od onoga što gubi; pružiti mu svoju strpljivost, vrijeme i blizinu kako bi osjetilo da smije biti tužno i da nije samo.

Djeca trebaju proći određene zadatke da bi mogla početi tugovati. Zadatak žalovanja u dječjoj dobi bio bi: ${ }^{25}$

- Razumjeti značenje riječi smrtna bolest ili riječ mrtav u konkretnim fizičkim nazivima, razumjeti uzroke smrti!

- Proraditi proces žalovanja koji obuhvaća stvaranje unutarnje prilagodbe na činjenicu da ga više neće biti!

- Nastaviti s aktivnostima primjerenima dobi ožalošćenoga djeteta!

Navodimo nekoliko roditeljskih postupaka koji mogu pomoći u pristupu olakšavanja procesa tugovanja kod djece:

- Potrebno je strpljivo odgovoriti na sva djetetova pitanja u vezi sa smrću, koristeći pri razgovoru s mlađom djecom primjere s igračkama, domaćim životinjama i kućnim ljubimcima.

- Ne preporučuje se reći djetetu da je premalo i da neće razumjeti o čemu je riječ.

25 Usp. I. BUZOV, Psihoanaliza žalovanja, Jumena - Jugoslovenska Medicinska Naklada, Zagreb, 1989., str. 87-88. 
- Dobro je reći djetetu kako se mi osjećamo u vezi sa smrću, razgovarati s djetetom o smrti.

- Nužno je omogućiti djetetu da u razgovoru iskaže sve vrste osjećaja.

- Dobro je upoznati dijete s običajima naše obitelji, vjere, kulture i uključiti ga, ako želi, u rituale (odlazak u crkvu, na pogreb, paljenje svijeća i drugo).

- Nužno je omogućiti djetetu da nastavi sa svakidašnjim aktivnostima (igra, odlazak u vrtić) onda kada to poželi.

- Nužno je biti strpljiv sa sobom i s djetetom.

Tugovanje zbog smrti djetetu bliske osobe određeno je kognitivnim i emocionalnim razvojem djeteta i predstavlja unutarnju borbu čežnje (za izgubljenim roditeljem, djedom ili bakom, bratom ili sestrom, prijateljem, kućnim ljubimcem) i suočavanjem $s$ činjenicom da ga više nema.

Period tugovanja može se, integrirajući elemente psihodinamike i razvojne psihologije, podijeliti na tri razdoblja: ${ }^{26}$

1. Početni period praćen je burnim emocijama i predstavlja akutnu fazu tugovanja koja traje od tri do dvanaest tjedana.

2. Drugo razdoblje dovodi do postupnoga psihološkog odvajanja od umrle osobe, traje jednu do dvije godine.

3. Završetak tugovanja predstavlja razdoblje u kojem je dijete steklo dovoljno emocionalnih kapaciteta za odnose s drugima i nove odnose nakon što je proradilo vlastite emocije.

Stručnjaci zauzimaju različita stajališta i provode mnoga istraživanja o tome jesu li djeca sposobna tugovati. Psiholog Worden većinu rezultata tih istraživanja nastojao je obuhvatiti na jednom mjestu, tvrdeći sljedeće: ${ }^{27}$

- Djeca pretežno uspiju elaborirati gubitak bliske osobe do prve ili druge godišnjice.

- Djeca su se bolje prilagodila gubitku u bolje povezanim obiteljima koje su se aktivno suočavale s nastalim gubitkom i koje su uspijevale naći nešto pozitivno u teškoj situaciji.

26 Usp. G. KUTEROVAC, Žalovanje u djece, u: M. Žužul, Z. Raboteg Šarić (ur.), Ratni stres u djece, MORH, Zagreb, 1992., str. 57-72.

27 Usp. J. W. WORDEN, Savjetovanje i terapija u tugovanju, Priručnik za stručnjake u području mentalnog zdravlja, Naklada Slap, Jastrebarsko, 2005., str. 160-162. Wordenova sinteza upotpunjuje se izvorima: J. H. HENDRIKS, D. BLACK, T. KAPLAN, Guiding Children through Trauma and Grief, Routledge, London, 2000.; C. A. CORR,

D. E. BALK (ur.), Handbook of Adolescent Death and Bereavement, Springer Publishing Company, 1996. 
- Otežano tugovanje javljalo se u djece čiji su preživjeli roditelji bili mladi, depresivni i zbog smrti doživjeli velik broj stresova i promjena.

- Bolje su funkcionirala djeca čiji je preživjeli roditelj i sam uspješnije prolazio tugovanje.

- Gubitak majke za većinu djece teži je od gubitka oca; veće su promjene u svakodnevnom životu, više je emocionalnih i ponašajnih promjena.

- Pozitivno je uključivanje djece u planiranje sahrane, daje im osjećaj važnosti i korisnosti u trenutcima kada je drugima iz njihove okoline teško.

- Djeca koja su bila jače povezana s umrlim roditeljem mogla su bolje pokazati svoju emocionalnu bol, o tome razgovarati i prihvatiti potporu.

- Nakon smrti roditelja djetetu je potrebna potpora i kontinuitet.

- Učinci zaruka ili novoga braka preživjeloga roditelja nakon odgovarajućega razdoblja tugovanja imali su pozitivan učinak na djecu.

U procesu tugovanja djeca imaju pravo:

- Znati da će se netko za njih brinuti!

- Znati da nisu ona izazvala smrt svojom ljutnjom ili nedostatcima!

- Imati jasnu informaciju o smrti, o njezinim uzrocima i okolnostima!

- Osjećati se važnima i uključenima na stalne, rutinske aktivnosti!

- Imati pristup nekomu tko će saslušati njihova pitanja!

Uskraćivanje nekih od navedenih prava može dovesti do toga da se proces tugovanja učini težim i dugotrajnijim ili pak preraste u kronično ili patološko tugovanje. Važno je omogućiti djetetu da prođe proces tugovanja jer, ako to ne učini, kasnije u životu može imati simptome depresivnosti, probleme u stvaranju bliskih odnosa s drugim ljudima te se teže suočavati s budućim kriznim situacijama ${ }^{28}$.

\section{Zaključak}

Holistička provedba integralne palijativne skrbi nužno zahtijeva interdisciplinarno sagledavanje percepcije smrti iz psihološko-kognitivnog i duhovno-emocionalnog kuta dječjeg iskustva. Stoga zdravstvene usluge pedijatrijske palijativne skrbi moraju ocijeniti i ublažiti dječju fizičku, psihološku, duhovnu i socijalnu uznemirenost. Da

28 Usp. A. VULIĆ-PRTORIĆ, Depresivnost u djece i adolescenata, Naklada Slap, Jastrebarsko, 2004., str. 192199 . 
bi to uspješno ostvarila, pedijatrijska palijativna skrb treba biti: koordinirana na svim mjestima pružanja skrbi; usmjerena prema djetetu i široko obiteljski orijentirana; usredotočena na olakšanje patnje i poboljšanje kvalitete života i za dijete i obitelj i usklađena s uvjerenjima i vrijednostima djeteta i skrbnika ${ }^{29}$.

Teškoće koje nam otežavaju takav pristup trebale bi biti nadvladane prilagođenom komunikacijom, pristupom i objašnjenjem djetetu ispravnom predodžbom teškoće neizlječivosti zdravstvenog stanja u kojem se osobno nalazi ono ili njegov bližnji. Trebalo bi mu na razumljiv i senzibilan način priopćiti da mu predstoji smrt, u skladu s kognitivnom percepcijom i mogućnošću prihvaćanja te započeti s vođenim protokolom psihološke adaptacije stadija žalovanja, uvažavajući širok raspon emocionalnih i duhovnih reakcija koje se mogu pri tome pojaviti.

Takav pristup zahtijeva i od samog medicinskog osoblja i skrbnika djece zajednički stav realnog predočavanja teških tema, poput smrti i žalovanja, za koje se zahtijeva puno obuhvatniji pristup koji empatijskom naklonošću, afektivnim vještinama i primjerenom komunikacijom nadilazi čisti profesionalizam.

Budući da holistički pristup pedijatrijske palijativne skrbi nužno zahtijeva interdisciplinarnu suradnju svih uključenih u praćenje djece s neizlječivom bolešću ili onih koji prolaze određene faze elaboracije osobnog predstojećeg gubitka zdravlja/ života ili gubitka bližnjega, važna je uska suradnja i ujednačena komunikacija svih uključenih u proces vođenja djece.

Preduvjeti uspješne komunikacije, udruženih smjernica za roditelje, uspjeha medicinskog i psihorehabilitacijskog tima za palijativni rad s djecom bili bi: ${ }^{30}$

- poznavati i razumjeti dobne norme dječjeg razvoja;

- pokazivati poštovanje i iskrenost;

- pokazivati povjerenje pomoću iskrenosti i dosljednosti u ponašanju;

- procijeniti djetetove potrebe u danoj situaciji;

- procijeniti djetetovu sposobnost uspješnog suočavanja s promjenama;

- prilagoditi jezično izražavanje djetetovoj razini razumijevanja;

- koristiti neverbalnu komunikaciju: dodir, ljuljuškanje, umirujući izraz lica;

- objasniti djetetu što zapravo znače njegove neverbalne poruke;

29 Usp. S. M. WANG, P. B. YOST, L. SENDER, Pediatric Palliative Care, u: N. Vadivelu, A. D. Kaye, J. M. Berger, Essentials of Palliative Care, Springer, New York, 2013., str. 444.

30 Usp. J. DESPOT LUČANIN, Komunikacija s osobama različite dobi, u: D. Lučanin, J. Despot Lučanin (ur.), Komunikacijske vještine u zdravstvu..., str. 111. 
- koristiti aktivno slušanje;

- umjesto razgovora koristiti i druge komunikacijske tehnike (pričanje priča, crtanje, kreativno pisanje) ili prijelazne objekte (omiljene igračke);

- koristiti igru za poticanje boljeg suočavanja: kreativnu, nestrukturiranu igru, igranje uloga, pantomimu i sl.;

Razmatranja bismo željeli privesti kraju poticajnim riječima koje je u jednom od svojih govora o odgovornost za najmanje na pedijatrijskom skupu okupljenima uputio blagopokojni papi Ivan Pavao II.:

„Prava djeteta daju se sažeti u pravo da budu ljubljeni od strane svojih roditelja; od strane zajednice da budu zaštićeni u svom djetinjem razvoju; a od strane znanosti da budu podržani zajedničkim programiranjem i koordinacijom svih ovih koji mogu osigurati neometane razvojne etape djetinjstva."

\title{
The perception of death and sorrow from a child's perspective in pediatric palliative care
}

\author{
SUMMARY
}

The inevitable fact of dying and death involves the most difficult aspect of palliative care that takes place in the pediatric clinical context. The implementation of the integral pediatric palliative care necessarily requires an understanding of the perception of death and mourning apprehension from the psychological-cognitive and spiritual-emotional point of child's experience of "global pain" experienced in the chronic illness and its terminal stage. Therefore, communication and empathic approach are of utmost importance, so that children can deal easier with the uncertainty and weight of their own condition or the loss of their loved ones. The palliative alleviation of child's grief can be significantly achieved through constructive guidelines of an interdisciplinary approach of developmental psychology, which could be carried out through the efforts of all involved in the child monitoring process to achieve the holistic conception of the palliative care.

Keywords: pediatric palliative care, death, mourning, psychology, communication. 